FACTA UNIVERSITATIS

Series: Law and Politics Vol. 16, N 3, 2018, pp. 213-224

https://doi.org/10.22190/FULP1803213D

Review Paper

\title{
CIVIL LIABILITY OF MINORS
}

\author{
UDC 347.515.1
}

\section{Mirna Dželetović}

Faculty of Law, University of Novi Sad, Republic of Serbia

\begin{abstract}
Damage caused to another person assumes tort liability, providing that all the conditions specified by the law are met. National law stipulates that children under 7 years of age are not liable for damage they have caused, while minors over 7 years of age, if capable of reasoning, can be held liable for damage compensation. A minor attains general tort liability at the age of 14. Considering the fact that minors can be held liable for damage caused to another, the Serbian Obligations Act ("Law on Contracts and Torts") makes a justifiable distinction between minors of different age regarding their individual liability. This distinction is not common in other European legal systems. Yet, the author concludes that it would be sensible to postpone the process of establishing tort liability of a minor for a later period, when the minor attains full contractual capacity. The conclusion is based on two main reasons. The first one is the fact that parental right, which last until the said age, implies the parents' obligation to take care of their underage child. The second reason is the financial situation of the child that prevents him/her from compensating the damage s/he has caused to another person.
\end{abstract}

Key words: damage, minor, parents, joint and several liability

\section{INTRODUCTION}

Regardless of the fundamental principle of prohibition of causing damage, which implies that one must refrain from actions that may cause damage to other persons, ${ }^{1}$ causing damage to to another person has been a common phenomenon leading to the establishment of the institute that would provide the plaintiff with an opportunity to rectify damage incurred by the tortfeasor's acts. This has led to the formulation of Civil Right principles that regulate infliction of damage and enable the aggrieved person to repair his/her status the legal status enhancement function (Vodinelić V., 2012: 484).

Received December $10^{\text {th }}, 2018$ / Accepted December $20^{\text {th }}, 2018$

Corresponding author Mirna Dželetović, PhD student, Faculty of law, University of Novi Sad, Republic of Serbia; E-mail: dzeletovicmirna@gmail.com

${ }^{1}$ Art. 16 of the Obligations Act (OA) on Contracts and Torts, Official Gazette SFRY, no. 29/78, 39/85, 45/89decision by CCY and 57/89, Official Gazette SRY, no. $31 / 93$ and Official Gazette of Montenegro, no. 1/2003Constitutional Charter. 
Both in theory and practice, there is no dilemma on who will bear the consequences for the damage if done by a person with full capacity. Consequently, the tortfeasor shall be responsible for the damage and shall, when all legal conditions are fulfilled, compensate the damage from his/her own property (by giving an item to replace the damaged one, or repairing the damaged item, or paying the monetary compensation, etc.) or by nonmonetary compensation (apology, declaration withdrawal, etc. (Vodinelić V., 2012: 485).

Dilemmas and different opinions exist in such situations where the tortfeasors are the minors whose parents are still obliged to look after them within the exercise of their parental right. ${ }^{2}$ Nowadays, it is obvious that minors enter the world of adults early. They come into contact with negative influences, values, patterns of behavior and upbringing at much earlier age through social networks, media and the environment. Considering that they are still in the process of maturation and personality development, they are often unable to distinguish acceptable from unacceptable behavior. Depending on the circumstances of each case, this can be attributed to a previous lack of good upbringing, a lack of adequate supervision, or the personality of the minor. Therefore, bearing in mind the aforementioned, it is completely reasonable to question whether it is justified that people who are responsible for the supervision of a minor shall be held responsible for the compensation of damage caused by the minor, or whether juvenile tortfeasors shall bear a certain degree of responsibility.

In the event of accepting the first solution, the person responsible for the incurred damage would not be the minor but some other person: for example, the parents (who are are responsible for the damage caused to another by their minor child), or the guardian, school or other institution while the child is under their supervision. Most international laws (as well as our legislation) provide that, under certain conditions (such as age and ability to reason), a minor can still be considered responsible towards the plaintiff, but in most cases the responsibility is placed on the parents or person supervising the minor at the time of causing the damage. These persons are most commonly charged according to the principles of subjective responsibility, which they can be absolved from if they prove that "the damage was incurred without their fault" 3 or that "they performed the supervision in the manner they were obligated to, and that the damage would have been caused even under a carefully conducted supervision." ${ }^{4}$ Our legal system is an exception because it distinguishes the damage incurred by a child under the age of 7 and establishes the objective responsibility of the parents regardless of fault. ${ }^{5}$ By enacting this legal solution, the legislator is generally believed to have given priority to the interests of the social environment, which is to protect itself from the increased risk of damage; given the fact that people are difficult to deter from the idea of having their own children, or to be forced to exercise responsible parenting, such strict responsibility for damage caused by a minor will not discourage the potential parents (Karanikić-Mirić, 2013: 228.)

\footnotetext{
${ }^{2}$ See Article 68 Family Act (FA), Official Gazette RS, no. 18/2005, 72/2011-other law and 6/2015.

${ }^{3}$ See Article 165 para. 4 of the Obligations Act (OA)

${ }^{4}$ See Article 167 para. 1 of the Obligations Act

${ }^{5}$ See Article 165 para. 1 of the Obligations Act
} 


\section{MINOR's RESPONSIBILITY FOR THE DAMAGE}

\subsection{The Obligations Act (on Contracts and Torts)}

The specificity of damage caused to another person by a minor stems from the dilemma concerning the age when a person can be considered capable of committing a civil delict (tort), and who should be held responsible for the damage caused by a child who obviously cannot be held liable in tort because s/he does not understand the serious consequences of the performed actions. Prior to the adoption of the Obligations Act (on Contracts and Torts), there was also a dilemma in court practice whether the same rules should apply to the parents of all minors, or only to those with children of a certain age (Draškić, 1988: $600)$.

The Obligations Act regulates the responsibility of minors in the section dealing with liability based on fault (culpability). This type of civil liability for damage is always established when the requisite conditions are fulfilled: the damage exists; it has been a result of an unlawful harmful action; there is a causal link between the illicit actions and the resulting damage; and there is a casual link between the tort capacity and the tortfeasor's culpability (Vizner, 1978: 678). What causes doubts about the responsibility of the minor for damage is precisely the fulfillment of the condition regarding the existence of a normal psychological disposition (capacity) of a minor to comprehend the causal link between the harmful action s/he takes and the consequences in terms of the damage that will occur from such an action (Subić, 1992: 1272).

As for the opinions on tort liability of minors found in theory, some authors suggest that attaining tort capacity is not related to certain age but it should be determined in each individual case, and if the minor responsible for the damage is proved to be capable of reasoning then s/he shall bear all the responsibility for the incurred damage. For example, Milošević believes that when damage is caused by a minor who has reached such a mental phase of development at which s/he can understand the significance of her/his actions, then $\mathrm{s} /$ he alone should take the responsibility regardless of whether it is a younger or older minor. He also states that the liability of a minor for the caused damage should be assessed in each particular case, based on the minor's ability to reason, by comparing her/his behavior with the one of a reasonable minor rather than the one of an adult. Furthermore, he thinks that tort liability needs to be proven separately, apart from the minor's criminal responsibility, because the conditions generating those two types of responsibilities are different, and the minor's ability to cause damage should not be equated with the minor's limited contractual capacity (Milošević, 1964: 262-263). This author also believes that efficiency-related reasons justify the aim to identify the liability of minors as the liability based on the principle of proven culpability, regardless of whether the tortious act has been committed by a minor between 7 and 14 years of age or a minor who has already turned 14, since the tortuous act committed by a minor is an expression of insufficient care of parents or other persons for a minor who is still at the stage of maturing and developing (Milošević, 1984:78).

In his work "Obligations and Contracts: A Draft for the Obligations and Contracts Code", Konstantinović suggested that minors capable of reasoning should also be held liable for the incurred damage (Konstantinović, 1996: 80). This solution does not assume the minor's age as a relevant element for proving tort liability but the fact that the minor is capable or incapable of reasoning, which is determined in each individual case. 
On the one hand, the stated attitudes assume the existence of responsibility of the minor whenever it is established that he is capable of reasoning at the moment the damage was incurred, whereby the minor's age is irrelevant; on the other hand, the Obligations Act (on Contracts and Torts) regulates the minor's responsibility by considering the age only as the starting criterion which distinguishes 3 periods. More precisely, national law regulates a minor's responsibility for damage by stipulating that a minor cannot be held responsible for the damage s/he causes until s/he turns seven. ${ }^{6}$ During this period of life, there is a legal presumption of minor's incapacity to commit torts, and the possibility of proving the opposite is excluded. Until the age of 7, minors are represented by their parents in all legal affairs. When the damage is caused by a minor between 7 and 14 years of age, s/he is not responsible for the damage unless it is proven that $\mathrm{s} /$ he was capable of reasoning at the time of causing the damage. ${ }^{7}$ Thus, in this period, incapacity is still presumed, but there is possibility of proving the opposite. Finally, a minor who has turned 14 may be held responsible for damage according to the general rules on liability for damage, ${ }^{8}$ on the basis of presumed guilt (culpability), i.e. regardless of guilt in the cases stipulated by the law.

Thus, depending on the minor's age, the law distinguishes three relevant periods in determining the responsibility of minors. While the possibility of proving the opposite is completely excluded in the first period (until the age of 7), the legal presumption of incompetence for reasoning in the second period (age 7-14) and the legal presumption of the ability to reason in the third period (after turning 14) are refutable (Vizner, 1978: 689). If the damage is caused by a child who is between 7 and 14 years of age, or by a child aged over 14, there is a possibility of proving the opposite. As for the first case, the burden of proof is on the plaintiff (i.e. the person who invokes the minor's liability), who has to prove the minor's capacity to reason at the time of causing damage. In the second case, the burden of proof falls on the party that claims that the minor was incapable of reasoning at the time of causing the damage. In case it has been successfully proven that the minor was capable of reasoning at the time of causing damage, the minor aged between 7 and 14 will be held liable for the damage.

Having in mind the analyzed regulation of the Serbian Obligations Act, national law prescribes that the acquisition of tort capacity, as the capacity of an entity to be responsible for damage (Vizner, 1978: 684), at the age when parental right is still exercised, which entails the right and obligation of parents to, among other, look after, raise and educate their child, ${ }^{9}$ as well as at the age which precedes the attaining of full contractual capacity, ${ }^{10}$ as a capacity to produce legal effects through one's own action (Vizner, 1978: 685). Minors who turned 14 and are capable of committing a tortious act have attained only partial capacity in that stage of life; thus, they can consciously undertake only a limited number of legal transactions recognized in the legal system. They can independently undertake ${ }^{11}$ legal transactions in order to obtain exclusive rights, or to perform some activities by which they obtain neither rights nor obligations, and perform legal transactions of minor importance. In order to undertake all other legal transactions, minors need the consent of their parents, or

\footnotetext{
${ }^{6}$ See Article 160 para. 1 of the Obligations Act

See Article 160 para. 2 of the Obligations Act

${ }^{8}$ See Article 160 para. 3 of the Obligations Act

${ }^{9}$ See Articles 67, 68 and 84 of the Family Act (FA)

${ }^{10}$ See Art. 11 FA.

${ }^{11}$ See Art. 64 FA.
} 
the guardianship authority in case of disposal of immovable property or movable property of great value.

Although this may lead to a conclusion that tort liability is impossible without tort capacity, the Obligations Act envisages such a possibility if it is required by the principle of fairness. ${ }^{12}$ The elements for establishing such liability are as follows: the damage was caused by an incompetent person (lacking legal capacity) who cannot be held liable; the compensation cannot be obtained from the person responsible for the supervision of an incompetent person; the request for compensation of damage caused by the incompetent person is assessed as fair and justified, and the incompetent person can compensate for the incurred damage (Carić et al., 1980: 518). The law leaves it to the court to assess the fairness and justifiability of the request for damage compensation by the incompetent minor who caused the damage by his/her actions, taking into account two essential circumstances: the financial situation of both the tortfeasor and the plaintiff.

On the one hand, considering these cases, there is practically a tortfeasor whose lack of capacity to reason makes him/her incompetent and thus not liable for the damage caused to the plaintiff; he is also in a better financial situation as compared to the plaintiff. On the other hand, the factual tortfeasor (who is considered incapable of committing a tortious act) is supervised by a person who is legally responsible for the damage caused to the plaintiff (as a presumptive torfeasor) but who cannot pay the compensation for the incurred damage. The assessment of fairness and justifiability of the compensation request represents an exceptional deviation in the case adjudication based on relevant and full application of positive regulations; the possibility of such adjudication is explicitly prescribed and allowed by the law in case when the present circumstances of the case lead to a conclusion and belief that the standard application of relevant provisions would be incompatible with the society's current ideas about fairness and justice (Vizner, 1978: 713-714).

\subsection{Joint and several liability of parents and children for damages}

According to the prescribed rules, a tortfeasor and his/her parents may be held liable for rectifying the damage caused by a minor. Thus, the question is raised as to whether they may be held jointly and severally liable. In Serbian legislation, parents and children may be held jointly and severally liable if, apart from parents, a child is also found to be responsible for the damage. ${ }^{13}$

In our legal system, there are two types of joint and several liability: joint and several liability between parents, and joint and several liability between parents and a child. Joint and several liability of parents arises from their failure to exercise the legal duty of mutual control over the minor, and the joint and several liability of parents and their child to the plaintiff is actually a tort liability, that is, joint and several liability of several persons for the same damage envisaged in Articles 206-208 of the Obligations Act (Vizner, 1978: 709). The share of each party that is jointly and severally liable for damage is commonly determined on the basis of the degree of their faults and the seriousness of consequences of their acts; in case it is impossible to determine the share of each party, each of them shall bear an equal share unless the principle of fairness requires a different decision on the merits of a specific case. ${ }^{14}$

\footnotetext{
${ }^{12}$ See Art. 169 of the Obligations Act (OA)

${ }^{13}$ See Article 166 of the Obligations Act

${ }^{14}$ See Article 208 of the Obligations Act
} 
In such situations, when the plaintiff claims compensation for damage from both parents and the minor, the minor shall be held liable on the grounds of subjective liability and fault, and the parents shall be liable on the grounds of liability for others. Considering that the Obligation Act has accepted the criteria of presumed fault and not proven guilt (culpability), in case of liability on the grounds of personal fault and liability for others, the burden of proof does not rest on the plaintiff but on the tortfeasor who has to prove that $\mathrm{s} / \mathrm{he}$ is not liable (Vizner, 1978: 709).

By analyzing our national legislation, it is clear that the applicable Obligations Act (on Contracts and Torts) stipulates that parents are liable for the damage caused by a child under the age of 7 . At this age, children can never be jointly and severally liable with their parents for compensation for damage caused to the aggrieved party.

This joint and several liability of parents and minor can only be established if the child causing the damage is between 7 and 14 years old, who was proven to be capable of reasoning at the time of causing the damage, and if it is a minor who reached the age of 14 and who is responsible for the damage according to the general rules on tort liability. ${ }^{15}$

It can be concluded that there are two possibilities when the damage is caused by a minor between 7 and 14 years of age. In case the child has tort capacity (ability to reason), both parents and the child shall be severally and jointly liable for the damage. Parents can be exonerated from this liability if it is proven that the damage was caused without their fault. However, in case the child at the mentioned age had no tort capacity (ability to reason), the parents shall be solely liable for the damage.

In theory, perceptions about joint and several liability of both parents and a 14-year-old minor who inflicted the damage are different. Some authors (such as Vizner) deny such a possibility because they believe that parents and children should be jointly and severally liable for the damage only if the damage is caused by a minor under the age of 14 , given the fact that minors who are over 14 can be solely responsible for the damage without holding their parents liable for their acts and on the assumptions that they are capable of reasoning (Vizner, 1978: 709).

On the other hand, Stanišić holds the opposite view; he believes that parents should be liable for the damage caused by their minors until they reach the age of 18 based on the principle of objective liability. This can be supported by the fact that parents are connected with their children by nature and can constantly have influence on their actions and decisions. The constitutional and legal duty of parents is to take care of property and personality of their children, to educate and supervise them. As a rule, children's bad behavior is the result of lack of control or poor education by parents themselves. There are rare cases when bad behavior of children is not the result of their parents' incorrect supervision and upbringing. Even in those cases, there is a justification for the liability of parents because the society has no conditions to otherwise provide the plaintiff with compensation for damage. Considering the living conditions in our country, he emphasizes that parents do not have means to fully compensate the plaintiff for the loss and the liability to the other person has been established in order to provide compensation for the aggrieved party (Stanišić, 1997: 23).

\footnotetext{
${ }^{15}$ Thus, as stated in the judgment rendered by the High Court in Valjevo 353/16 on September 01, 2016 (Ingpro paket $10+$ database), parents and a child were jointly and severally liable for damage the child inflicted to the other person when s/he was at the age of 17. The Court upheld that the tortfeasor was liable on the grounds of fault in accordance with Article 154 para. 1 of the Obligations Act (OA) and Articles 158 and 160 para.2 of the OA, while the parents were liable based on the provisions in Article 165 para. 4 of the OA.
} 
Although there are different opinions in theory regarding the joint and several liability of parents and minors over the age of 14, the court practice is unified about this joint and several liability and supports its existence. This is based on the point that the liability of parents in such cases arises from the fact that parents have not proved that the damage was caused without their fault; so, they neglected taking care of their minor and, consequently, this has led to causing damage (Šemić, 1999: 92).

\subsection{The Draft Civil Code of the Republic of Serbia}

In addition to the applicable Obligations Act, the liability of minors for causing damage is regulated in the working draft of the Civil Code of the Republic of Serbia, ${ }^{16}$ Chapter 2, Section 2 regulating Liability on the grounds of fault (Articles 299-305). There are three age groups relating to liability of minors, and the age limits between the groups has not been changed. ${ }^{17}$ Minors who have not reached the age of 7 cannot be held liable for the damage they have caused. Minors who are 7 to 14 years old are generally not liable for the damage they have caused. The difference between this working draft and the effective regulations is that, in case a minor causes damage to another person in this period of life, the burden of proving the liability of the minor, i.e. the burden of proving the minor's ability to reason at the time of causing the damage, shall be borne by the opposite party/plaintiff ('unless the opposite party proves that the minor was capable of reasoning when causing the damage'). ${ }^{18}$ Finally, a minor who is 14 years old may be liable for the caused damage according to the general rules on tort liability.

The Draft Civil Code also includes a provision on joint and several liability of both parents and children, ${ }^{19}$ without introducing any changes as to the applicable Obligations Act (on Contracts and Torts). Thus, except for the provision that explicitly stipulates that the burden of proof of the minor's ability to reason when causing the damage shall be borne by the opposite party (plaintiff), there are no other changes in the working draft of the Civil Code.

\subsection{Overview of Comparative Law}

Comparative legislation also suggests similar solutions, stipulating that both minors and people in charge of their care and supervision may be held responsible for the damage caused by minors. When it comes to the European legal systems, different solutions are suggested regarding the responsibility of a child.

One of the solutions implies setting the age limit under which the child cannot be held liable for causing damage to another person. This age limit at which children are not considered liable for their tortious acts differs from one country to another. For example, The German Civil Code $(B G B),{ }^{20}$ in Article 828, stipulates that a minor who has not turned 7 yet is not responsible for damage caused to another person, while a minor at the age between 7 and 10 is not responsible for damage in an accident involving a motor vehicle or

\footnotetext{
${ }^{16}$ Draft Civil Code of the Republic of Serbia (working draft, 29 May 2015), retrieved on 3 April 2018 from https://www.mpravde.gov.rs/files/nacrt.pdf,

${ }^{17}$ See Article 301 of the Serbian Draft Civil Code (Draft CC)

${ }^{18}$ See Article 301 of Draft CC

${ }^{19}$ See Article 308 of Draft CC

${ }^{20}$ German Civil Code $(B G B)$, available at

https://www.gesetze-im.internet.delenglisch_bgb/englisch_bgb.html\#p3501, April 06, 2018.
} 
railway, provided that $\mathrm{s} / \mathrm{he}$ did not cause the damage intentionally. The same provision stipulates that a minor who has not reached the age of 18 is not responsible for damage cause to another person if s/he is not aware of her/his responsibility. Therefore, it can be concluded that the liability of the child over the age of 7 (i.e. the age of 10 ten in case of damage in an accident involving vehicle or railway) or a minor under the age of 18 depends on her/his ability to reason. ${ }^{21}$ The age of 7 is also a limit in Portuguese law, according to which the children who are 7 years old or older are responsible for the damages caused to other persons (Pereira, 2005: 638). It is believed that this age has been chosen based on the German law since it does not comply with the educational system of Portugal, where children start elementary school at the age of six (Veroso, 2006: 312). This age limit is increased in Austrian law system since it is a general rule for the minors under 14 not to be responsible for damage caused to another person but there is still a possibility for the opposite party to prove the contrary. ${ }^{22}$ Even if the minor is found liable (culpable) for damage, the court can only oblige her/him to bear a fair share of responsibility for damage. The first reason for such a legal solution would be the fact that mental abilities of a minor have not been developed yet; so, given the same circumstances, the courts are more lenient in sentencing a minor in comparison to sentencing an adult. The second reason would be the fact that, in case of determining the liability and compensation for damage, the financial situation of both the plaintiff and the tortfeasor should be taken into account, which can result in reduction of compensation due to poor finances of the minor. Nevertheless, the minor's liability is subsidiary to the liability of the parents or other persons who are obliged to exercise care and supervision over the minor (Hirsch, 2006:7-8).

On the other hand, some legal systems do not set this age limit. Italian law, for instance, does not set the minimum age at which a child should be held liable for the incurred damage, which further means that minors can be held responsible for damage based on the general provisions of the Italian Tort Law, provided that they were capable of understanding the consequences of their acts or failures at the time of causing the damage (Comande, Nocco, 2006: 267-268). The child's responsibility is assessed with respect to the type of case. Whereas criminal legislation explicitly specifies the reasons for nonculpability, in civil law it is the discretionary authority of the judge to assess the merits of the case and form his/her opinion based on intellectual and physical abilities of a child, his/her behavior, education and similar criteria that are taken into account in determining the child's civil liability. Therefore, in order to be held liable for damage, the child should be able to act reasonably, to understand the risk of her/his actions or to manage her/his behavior towards achieving some goals. However, in practice, children who have not reached the age of 6 yet are not usually held responsible for damages. For this reason, the Italian Supreme Court of Cassation pointed out that, in case of determining the child's responsibility, it was not enough for the Court to take into account the child's age and caused damage in assessing his/her liability; besides the intellectual capacity and physical abilities, personality characteristics and development, the court should also consider the ability of a child to understand the illegal nature of his/her acts and the ability to make sensible choices (Comande, Nocco, 2006: 269-270).

\footnotetext{
${ }^{21}$ Miguel Martin-Casals, Children in Tort Law Part 1: Children as tortfeasors, Comparative report 2005, civil.udg.edu/children/Reports.htm, accessed June 30, 2018;

${ }^{22}$ Children in Tort Law, available at http://civil.udg.edu/children/project02.htm ( accessed April 03, 2018)
} 
Just like the Italian legislation, the Spanish Civil Law does not set the age limit below which the children cannot be held responsible for causing damage, nor does it set the age limit above which they can be held liable for their tortious acts. The liability is determined based on the type of case, which implies that in case of determining the liability on the grounds of fault, the child's tort capacity should be assessed first. The child's tort capacity entails the ability to understand and wish to commit a tortious act, but it depends on the child's ability to understand what it means to do harm to another (from the perspective of his/her intellectual characteristics). In the event that tort capacity of a child is determined based on these criteria, the child will be held liable damage caused by his/her torious act (Martin-Casals, Ribot, Feliu, 2006: 369-370).

In France, after a series of decisions in $1984,{ }^{23}$ it was decided that children were responsible for their torts irrespective of the lack of ability to reason. Minors are always held responsible for damage they cause regardless of their age and abilities. Their ability to distinguish right from wrong is of no relevance. ${ }^{24}$

Despite obviously different legal solutions on children's civil liability in tort, the common characteristic in a vast majority of legal systems is the establishment of tort liability on the grounds of fault, based on the child's ability to reason. However, opinions differ regarding the understanding of what the said ability to reason actually implies. In some legal systems, it refers to the ability to act voluntarily, while in other legal systems it also implies the child's ability to recognize responsibility for his/her dangerous actions. ${ }^{25}$

In addition to the ability to reason, the other question that arises is the applicable standard of care in their behavior that children have to meet in order to avoid liability. In some legal systems, the burden is placed on minors because their behavior is assessed according to the general standard of reasonable behavior that is required from an adult. In other systems, such as the English one, the children's behavior is assessed on the basis of the standard of care that has to be met by a child of a similar age and acting in similar circumstances. ${ }^{26}$

\section{CONCLUSION}

This paper analyzes the possibility and conditions under which minors can be held liable for causing damage to others. Although most legal systems allow this possibility, provided that the necessary requirements are fulfilled, persons who are most often held liable for damage caused by minors are those who are supposed to supervise and/or take care of them, primarily their parents. Assigning responsibility to parents and other guardians for damage cused by minors in their care is justifiable because Tort Law is primarily aimed at defending the interest of the aggrieved party and mitigating the consequences of damage caused by the tortfeasor. Considering the minors' financial situations, iIt may be difficult to fulfill this aim if the damage has to be rectified by minors

\footnotetext{
${ }^{23}$ Miguel Martin-Casals, Children in Tort Law Part 1: Children as tortfeasors, Comparative report 2005, civil.udg.edu/children/Reports.htm, June 30, 2018

${ }^{24}$ In the cases of Derguini, Lemaire and Gabillet, the Court held that judges should not take into account whether a child was able or not to understand the consequences of his/her acts. France-Decisions regarding children in tort law, civil.udg.edu/children/Decisions.htm, June 30, 2018

${ }^{25}$ Children in Tort Law, civil.udg.edu/children/project02/, May 03, 2018

${ }^{26}$ Ibid.
} 
alone. On the other hand, bearing this responsibility has a preventive impact on the aforementioned persons, reminding them of the fact that they are obliged to provide proper care and supervision of minors.

The effective Obligations Act (on Contracts and Torts) and the working draft of the Civil Code of the Republic of Serbia justifiably make a distinction between minors of different age in terms of their tort liability for caused damage. This is necessary because there is no dispute that the liability of a 5-year-old child cannot be equated and treated in the same manner as the liability of a 13-year-old child. However, it seems right to change the current age limit at which tort liability is attained, and to equalize it with the age of maturity or the age when full contractual capacity is attained before maturity. The parental rights and obligations, which imply the parents' responsibility to look after their children and consequently their liability for failure to supervise the child who caused damage to another, typically end when a child reaches the age of maturity, or when s/he attains full contractual capacity before the maturity age. In addition, although assuming tort liability in younger ages and before attaining the full contractual capacity can be justified from the aspect of prevention and raising minors' awareness of the need to take responsibility for their actions, this responsibility can be of little practical significance for the aggrieved party and for rectifying the damage. In the majority of lawsuits over damage indemnification, the tortfeasor is obliged to compensate the damage financially, which a minor is unable to do due to the lack of financial means.

It seems unjustifiable to accept the standpoints articulated in legal theory according to which tort liability should be determined in each particular case, without setting the age limit below which the minor cannot be held responsible for the damage or the age over which s/he can be held liable for damage. Such a solution would often result in long evidentiary hearing procedure aimed at determining whether the minor was capable of reasoning or not at the time of causing damage to another person, that is, whether s/he may be held liable in tort or not. Even if the minor were considered capable of reasoning and making judgment and held liable for the incurred damage, the proceeding would result in a final (binding) decision which would be difficult to enforce in practice for the previously stated reasons regarding the minor's financial standing.

In addition, it seems unjustifiable to accept the view that parents should not be held jointly and severally liable for damage caused by minors who have turned 14 due to the fact that these minors can be fully responsible for the committed torts. In this case, the counterarguments are the parental right, which still has not ended in that period of child's life, as well as the financial standing of the minor, who is still at school in the period from the age of 14 to 18 . It seems that the court practice has reached the most appropriate solution by deciding that the minor's parents may be held jointly and severally liable with the minor for the damage caused to the plaintiff, even when the minor has already turned fourteen. 


\section{REFERENCES}

Antić, Oliver (2012). Obligaciono pravo, Pravni fakultet Univerziteta u Beogradu, Centar za izdavaštvo i informisanje, Beograd;

Carić, Slavko (ed.); Đorđević, Živomir; Goldštajn, Aleksandar; Jankovec, Ivica; Mitrović, Dobrosav; Perović, Slobodan; Pop-Georgiev, Dimitar; Radišić, Jakov; Stanković, Vladan; Stojanović, Dragoljub; Trajković, Miodrag (1980). Komentar Zakona o obligacionim odnosima, Pravni fakultet Univerziteta u Kragujevcu, Kulturni centar Gornji Milanovac, Kragujevac-Gornji Milanovac 1980

Comande, Giovanni; Nocco, Luca (2006). Children as tortfeasors under Italian law, Children in Tort Law Part 1: Children as tortfeasors, vol. 17, Springer, Wien-New York 2006.

Draškić, Marija (1988). Odgovornost za drugog, Zakon o obligacionim odnosima:1978-1988: knjiga o desetogodišnjici, tom 1, Savez udruženja pravnika SR Srbije, Beograd 1988

Hirsch, Susanna (2006). Children as tortfeasors under Austrian law, Children in Tort Law Part 1: Children as tortfeasors, vol. 17, Springer, Wien-New York 2006.

Karanikić Mirić, Marija (2013). Objektivna odgovornost za štetu, Pravni fakultet Univerziteta u Beogradu, Centar za izdavaštvo i informisanje, Beograd 2013.

Konstantinović, Mihailo (1996). Obligacije i ugovori, skica za zakonik o obligacijama i ugovorima, Službeni list SRJ, Beograd 1996;

Martin-Casals, Miguel (2005). Children in Tort Law Part 1: Children as tortfeasors, Comparative report 2005, available at: civil.udg.edu/children/Reports.htm

Martin-Casals, Miguel; Ribot, Jordi; Sole Feliu, Josep (2006).Children as tortfeasors under Spanish law, Children in Tort Law Part 1: Children as tortfeasors, vol. 17, Springer, Wien-New York 2006.

Milošević, Ljubiša (1964). Odgovornost maloletnika za štetu-građanskopravna (deliktna) odgovornost maloletnika, Anali Pravnog fakulteta u Beogradu: tromesečni časopis za pravne $i$ društvene nauke 23/1964, Pravni fakultet Univerziteta u Beogradu; pp. 262-263.

Milošević, Ljubiša (1984). Obligacionopravna (materijalnopravna) odgovornost roditelja i drugih lica za štetne radnje maloletnika, Zbornik Matice srpske za društvene nauke 77/1984, Matica Srpska, Novi Sad.

Pereira, Andre Goncalo Dias (2005). Portuguese Tort Law: A comparison with the Principles of European Tort Law, European Tort Law 2004, Springer, Wien-New York 2005;

Salma, Jožef (2007). Obligaciono pravo, Pravni fakultet Univerziteta u Novom Sadu, Centar za izdavačku delatnost, Novi Sad 2007;

Stanišić, Vukašin (1997). Odgovornost roditelja za štetu koju prouzrokuju njihova maloletna deca, Izbor sudske prakse:stručno-informativni časopis 7/8, Glosarijum, Beograd 1997;

Subić, Milan (1992). Odgovornost za štetu koju prouzrokuju maloletnici, Pravni život 9-10, Udruženja pravnika Srbije, Beograd 1992;

Šemić, Milan (1999). Prouzrokovanje i naknada štete, Gradska narodna biblioteka "Žarko Zrenjanin", Zrenjanin 1999;

Veloso, Maria Manuel (2006). Children as tortfeasors under Portuguese law, Children in Tort Law Part 1: Children as tortfeasors, vol. 17, Springer, Wien-New York 2006.

Vizner, Boris (1978). Komentar Zakona o obveznim (obligacionim) odnosima, vlastita naklada, Zagreb

Vodinelić, Vladimir V. (2012). Građansko pravo- Uvod u građansko pravo i opšti deo građanskog prava, Pravni fakultet Univerziteta Union u Beogradu, JP Službeni glasnik, Beograd 2012;

\section{LEGISLATION:}

German Civil Code (BGB), Retrived 23 May 2018 from https://www.gesetze-im-internet.de/englisch_ bgb/englisch_bgb.html\#p3501

Građanski zakonik Republike Srbije (radni tekst), 29.maj 2015, Vlada Republike Srbije, Komisija za izradu Građanskog zakonika, Retrived 20 May 2018 from https://www.mpravde.gov.rs/files/nacrt.pdf

Porodični zakon (Family Act), Službeni glasnik RS, br. 18/2005, 72/2011-dr. zakon i 6/2015.

Zakon o obligacionim odnosima (Obligations Act), Službeni list SFRJ br. 29/78, 39/85, 45/89-odluka USJ i 57/89, Službeni list SRJ br. 31/93, i Službeni list SCG br. 1/2003-Ustavna povelja;

Internet sources:

Project: Children in Tort Law, Retrived 11 April 2018 from civil.udg.edu/children/project02/

Presuda Višeg suda u Valjevu Gž.353/16 od 01. septembra 2016. godine (Judgment of the High Court in Valjevo Gž. no.353-16, 1 Sept.2016), in Ingpro paket 10+ database, Retrived 15 June 2018 from www.ingpro.com 


\section{GRAĐANSKOPRAVNA (DELIKTNA) ODGOVORNOST MALOLETNIKA ZA ŠTETU}

Prouzrokovanje štete drugom, uz ispunjavanje zakonom propisanih uslova, vodi građanskopravnoj odgovornosti za štetu. Domaće pravo propisuje da deca mlađa od sedam godina ni u kom slučaju ne mogu biti odgovorna za štetu koju prouzrokuju, dok se maloletnici stariji od sedam godina ukoliko su sposobni za rasuđivanje mogu pojaviti kao odgovorna lica za naknadu štete. Sa navršenih četrnaest godina maloletnik odgovara prema opštim pravilima o odgovornosti za štetu. Kada je već prihvaćeno da maloletnici mogu da odgovaraju za štetu koju su prouzrokovali drugom, Zakon o obligacionim odnosima opravdano pravi razliku u uzrastu maloletnika prilikom uređivanja njihove odgovornosti. Pravljenje ovakve razlike nije karakteristično za prava drugih evropskih zemalja. Ipak, autor zaključuje da bi bilo mesta odlaganju sticanja deliktne sposobnosti na kasniji period, odnosno period kada se stiče potpuna poslovna sposobnost. Dva su glavna razloga za ovakav zaključak. Prvi bi bio taj što do tog doba traje roditeljsko pravo iz kog proističe pravo i dužnost roditelja da se staraju o svom maloletnom detetu. Drugi bi bile materijalne prilike maloletnika zbog kojih on teško da može udovoljiti obavezi naknade štete koju je pričinio drugom.

Ključne reči: šteta, maloletnik, roditelji, solidarna odgovornost 